\title{
Molluscs' Composition and Distribution in Mangroves of the Cameroon Central Coast
}

\author{
Ernest Flavien Kottè-Mapoko ${ }^{1}$, Vanessa Maxemillie Ngo-Massou ${ }^{1,2}{ }^{\text {Léopold Guillaume }}$ \\ Essomè-Koum ${ }^{1}$, Jean Michel Emane ${ }^{1}$, Laurant Nyamsi Moussian ${ }^{1}$, Richelieu Tchoffo ${ }^{1}$, \\ Ndongo Din ${ }^{1 *}$
}

${ }^{1}$ Department of Botany, Faculty of Science, the University of Douala, Douala-Cameroon

${ }^{2}$ Department of Biological Sciences, Higher Teacher's Training College, the University of Yaoundé, Cameroon.

\begin{abstract}
Mangroves play relevant roles in coastal communities. Despite their high values, they suffered from human pressures which have caused biodiversity reduction and death of species unable to adapt to change. This survey aims to evaluate the diversity of mangrove molluscs, determine their distribution within stands and identify potential biological indicators in relation with the level of mangrove depletion. Study areas were selected between Limbe and Kribi. Transects were opened perpendicularly to the main channels. Molluscs were identified or encoded and counted within $1 \times 1 \mathrm{~m}^{2}$ quadrats. More than 14,400 individuals grouped into 34 species and 15 families were recorded. With 8 species, Neritinidae was the most species richness while Pachymelaniidae and Pachymelania fusca was respectively the most abundant family (54.5\%) and species (26.6\%). The highest species richness was obtained in Yoyo $(M I=2.8)$ while Douala has shown the highest abundance $(166.7 \pm 74$ ind. $m-2)$ and species diversity $\left(H^{\prime}=3.38\right)$. The census increased the Cameroun mangrove molluscs composition with five undetermined species, a Pachymelania sp. and two identified species. Three species ( $P$. fusca, Tympanotonus fuscatus and T. radula) appeared tolerant to mangrove degradation while eleven others seemed to be adapted only to their local conditions.
\end{abstract}

Keywords: Biodiversity, Macrobenthos, Neritina adansoniana, Neritina lineolata, Pachymelania fusca var mutans, Tympanotonus spp.

\section{INTRODUCTION}

Mangroves are important in the protection of coasts against the erosive effects of floods, waves, storms, hurricanes or tsunamis [1,2]. They help in filtering pollution and the quality of coastal waters [3], and in the natural treatment of swamp wastewaters [4]. Mangroves also fix atmospheric $\mathrm{CO}_{2}$ and thus contribute to the fight against global warming [5]. Mangroves play a role in fisheries, agriculture [6] and shrimp farming [7]. Mangrove forests are known to provide feeding grounds, nursery sites and protection areas for vertebrates and invertebrates [8].

This forest create unique ecological ecosystems that host rich assemblages of diverse taxa associated with different habitats. The muddy or sandy sediments are home to a variety of epibenthic or endobenthic, macro-invertebrates and meio-invertebrates [9]. Benthic invertebrates represent an important group in the mangrove food web and thus strongly influence the energy flows in this ecosystem. In addition, benthic organisms mediate nutrient remineralization in the sediment. Crabs and molluscs are the predominant animals in the mangrove forest and are thought to play a significant ecological role in the structure and functioning of this ecosystem [10, 11]. They form the important link between the primary detritus at the base of the food web and consumers of higher trophic levels [12]. Molluscs occupy all compartments of the food web as predators, herbivores, scavengers and as filter feeders. They include both mobile and stationary species and are distributed horizontally (along the sea axis) and vertically (at various heights of the earth). Despite their multiple ecological roles in this ecosystem, some aspects of mangrove molluscs is not clear yet [13].

Mangrove forests are subjected to strong degradation worldwide despite the high values of these ecosystems. Disturbances in mangroves have been attributed to a combination of factors such as human pressure on coastal lands, sea-level rise, and absence of adequate legislation regarding mangrove protection, and pollution in the peri-urban settings [14]. Mangroves in Cameroon have been 
substantially reduced in areas because the trees have been cut down to provide firewood, poles, timber, etc. and land has been reclaimed for settlement, sand extraction and implementation of some state's projects for urbanization of the cities such as Douala, Limbe and Kribi [15, 16].

Data on Cameroon mangroves biodiversity remain relatively poor, incomplete and unevenly distributed [17, 118, 19]. Studies on molluscs are limited to Plaziat [20], who showed the distribution of amphibious molluscs of some littorals and estuaries with mangrove, followed by Bandel and Kowalke [21] on gastropod fauna, and Ngo-Massou et al. [11] interested on the two major groups of mangrove macrobenthos. Data from these surveys have reported that the composition of molluscs in Cameroon mangroves has 39 species including 26 genera and 19 families [11]. The rapid degradation of mangroves in Cameroon requires the speeding up of scientific mobilization on sensitive sites.

The loss of habitat leads forcefully to the disappearance of sensitive biological communities such as many macrobenthos species which are unable to adapt elsewhere. Community composition depends on habitat stability which makes possible the growth of the resident populations. Thus, their diversity and abundance could already reflect the status and functioning of the mangrove ecosystem and serve as potential biological/ecological indicators of habitat alteration [10]. In order to improve data on the mangrove biodiversity under different anthropogenic pressures, this survey aims (1) to evaluate the diversity of mangrove molluscs, (2) to determine the distribution within six stands and (3) identify potential biological indicators in relation with the level of mangrove depletion in the Cameroon central coast.

\section{MATERIAL AND METHODS}

\subsection{Study Area}

The study was carried out between Limbe and Kribi (Figure 1) where mangrove stands are dominated by Rhizophora spp. Six sampling stations were selected based on the level of vegetation degradation. The climate, soil and biological conditions of the areas have been well described by previous documents $[11,14,15,16,17,18,22]$.

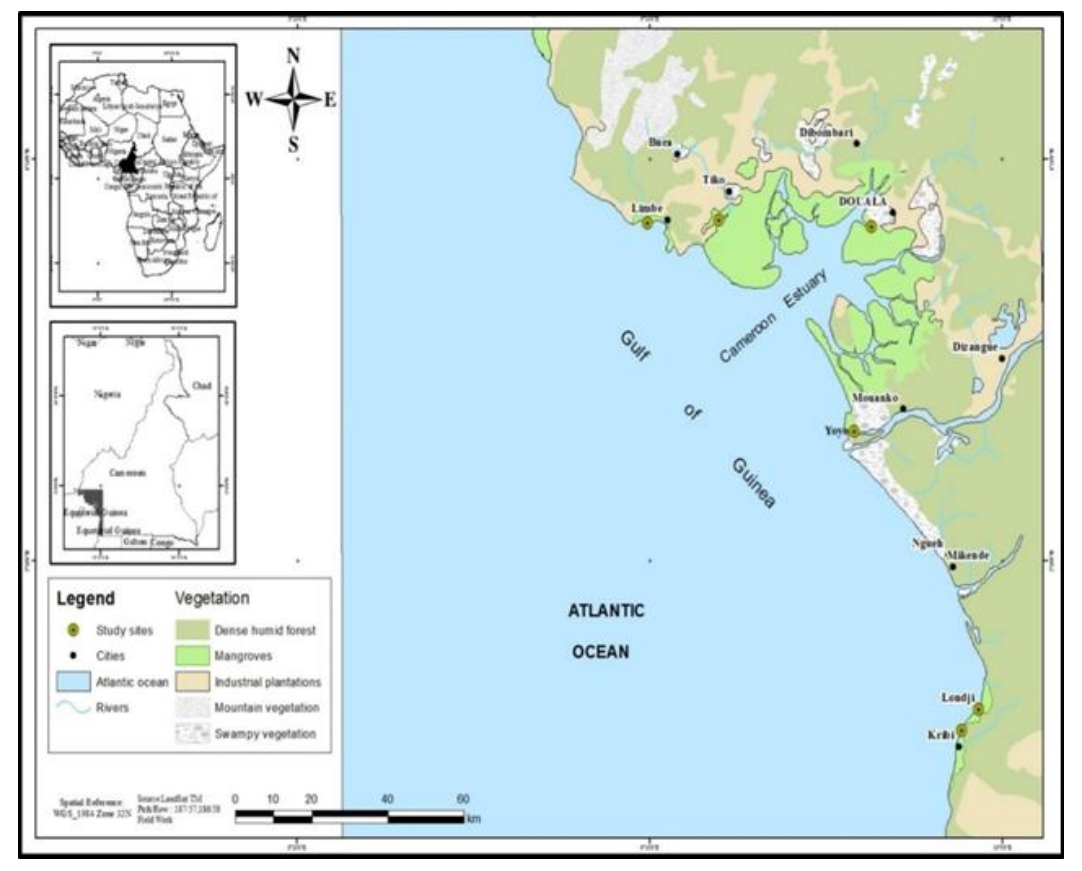

Figure1. Map showing study area (adapted from Din [17]).

\subsection{Molluscs' Survey}

Sampling was done at the low neap tide and then repeated at the low spring tide. Mangrove forest was divided from landward to seaward into three main zones: landward fringe, tree species belts, sand flat or mudflat. To assess the abundance and diversity of the mollusc populations in each station, two sampling strategies were used and data pooled. Visible molluscs were caught by hand within $1 \times 1 \mathrm{~m}^{2}$ quadrats on both sides of the transects. Arboreal species in each quadrat were hand-picked from trees on the plot surface. Organisms were sorted out by eye, identified when possible in the field to family, generic or specific level and counted. Collected specimens were put in cold water for several minutes 
for sedation, and then washed and stored in labelled tablet jars containing $70 \%$ alcohol. In the laboratory, identification procedure of specimens was continued using available local data [11, 20, 21] and molluscs database (www.molluscabase.org) or Marine Species Identification Portal (www. species-identification.org.com) websites. Nomenclators of gastropods and bivalves follows Bouchet and Rocroi [23, 24].

The assessment of biological indicators in relation with mangrove degradation was conducted following the passive monitoring approach [25, 26, 27]. Sensibility or tolerance was related to presence/absence and abundance of molluscs' species within study sites.

\subsection{Data Analysis}

Data were analyzed using univariate and multivariate techniques. The abundance, species richness (Margalef index), relative frequency and relative densities were assessed according to Ludwig and Reynolds [28]. Likewise, diversity index of Shannon-Weaver (H') and the evenness index of Pielou was calculated. An additional index named the common-species index, was assessed as, one minus the minimum proportion of total species needed to make up one half the total number of individuals [29]. The latter index ranges from 0.5 to 1.0 , with values closer to 1 indicating that the fauna is dominated by just one or a few species. Comparison between different stations was investigated by means of a dendrogram using Bray-Curtis similarity. The results were expressed as a hierarchical agglomerative clustering using simple linkage among all study stations. Data were treated with the help of "PAST v.3.05" software [30].

\section{RESULTS AND DISCUSSION}

\subsection{Molluscs' Composition and Diversity}

Investigations of molluses in all stations have produced a total of 14,426 individuals segregated into 15 families (Table 1). These species were ranged in two classes (Gastropods and Bivalves). These two classes are part of the main wildlife shellfish in mangrove habitats [8]. Gastropods with 30 species grouped in twelve families (Achatininae, Littorinidae, Melanopsidae, Muricidae, Neritilidae, Neritinidae, Pachymelaniidae, Potadomatinae, Potamididae, Thaididae, Theodoxinae and Thiaridae) was the most important. The Neritinidae was the most represented familly with eight species, followed by Pachymelaniidae with seven species. Thiaridae was represented by three species. Littorinidae, Potamididae and Theodoxinae were consisted of two species while Achatininae, Melanopsidae, Muricidae, Neritilidae, Potadomatinae and Thaididae were represented by a sole species each. The Pachymelaniidae family had the highest abundance $(54.5 \%)$, more than twice the second (Potamididae: 23.38\%) and more than a thousand times the Achatininae which was the last. Budiarsan and Rizal [31] state that large numbers of gastropods lived with Rhizophoraceae vegetation in muddy substrates and are found in large colonies in areas flooded with sea water. This vegetation commonly dominates the mangrove forest in Cameroon.

Table1. Composition of collected molluscs and habitats. FRD, family relative density (\%); Dw, Deadwood; Pr, Plant root; Ps, Plant stem; Sb, Substratum; UDx, undetermined species number x.

\begin{tabular}{|c|c|c|c|c|}
\hline Class & Families & FRD & Species & Habitats \\
\hline \multirow{4}{*}{ Bivalves } & Crassostreidae & 0.90 & Crassostrea gasar (Dautzenberg 1891) & $\operatorname{Pr}$ \\
\hline & Cyrenoididae & 0.16 & Cyrenoida rosea (d'Ailly 1896) & $\mathrm{Sb}$ \\
\hline & \multirow{2}{*}{ Donacidae } & \multirow{2}{*}{2.82} & Iphegenia rostrata (Römer 1869) & $\mathrm{Sb}$ \\
\hline & & & Egeria radiata (Lamarck 1804) & $\mathrm{Sb}$ \\
\hline \multirow{14}{*}{ Gastropods } & Achatininae & 0.05 & Achatina achatina (Linnaeus 1758) & $\mathrm{Sb}$ \\
\hline & \multirow{2}{*}{ Littorinidae } & \multirow{2}{*}{0.87} & Littorina angulifera (Lamarck 1822) & Pr or Ps \\
\hline & & & Littorina sp. & Pr or Ps \\
\hline & Melanopsidae & 1.56 & Melanopsis sp. & $\mathrm{Sb}$ \\
\hline & Muricidae & 0.20 & Murex sp. & $\mathrm{Dw}$ or $\mathrm{Sb}$ \\
\hline & Neritiliidae & 0.10 & Neritilia rubida (Pease 1865) & $\mathrm{Sb}$ \\
\hline & \multirow{8}{*}{ Neritinidae } & \multirow{8}{*}{3.11} & Neritina adansoniana (Récluz 1841) & $\mathrm{Dw}, \mathrm{Pr}$ or $\mathrm{Sb}$ \\
\hline & & & Neritina glabrata (Sowerby 1849) & $\mathrm{Dw}, \mathrm{Pr}$ or $\mathrm{Sb}$ \\
\hline & & & Neritina lineolata (Lamarck 1816) & Pr or $\mathrm{Sb}$ \\
\hline & & & Neritina senegalensis (Gmelin 1791) & $\mathrm{Sb}$ \\
\hline & & & UD1 & $\mathrm{Sb}$ \\
\hline & & & $U D 2$ & $\mathrm{Sb}$ \\
\hline & & & UD3 & $\mathrm{Sb}$ \\
\hline & & & UD4 & Dw, Pr or $\mathrm{Sb}$ \\
\hline
\end{tabular}




\begin{tabular}{|c|c|c|c|}
\hline \multirow{7}{*}{ Pachymelaniidae } & \multirow{7}{*}{54.55} & Pachymelania aurita (Müller 1774) & $\mathrm{Sb}$ \\
\hline & & Pachymelania byronensis (Wood 1828) & $\mathrm{Sb}$ \\
\hline & & Pachymelania fusca (Gmelin 1791) & $\mathrm{Sb}$ \\
\hline & & Pachymelania granifera $($ Gmelin,1791) & $\mathrm{Sb}$ \\
\hline & & Pachymelania mutans (Gmelin 1791) & $\mathrm{Sb}$ \\
\hline & & Pachymelania sp.1 & $\mathrm{Sb}$ \\
\hline & & Pachymelania sp. 2 & $\mathrm{Sb}$ \\
\hline Potadomatinae & 4.44 & Potadoma Liricincta (Smith 1888) & $\mathrm{sb}$ \\
\hline \multirow{2}{*}{ Potamididae } & \multirow{2}{*}{23.38} & Tympanotonus fuscatus (Linnaeus 1758) & $\mathrm{Sb}$ \\
\hline & & Tympanotonus radula (Linnaeus 1758) & $\mathrm{Sb}$ \\
\hline Thaididae & 0.93 & Thais callifera (Lamarck 1822) & Dw or $\mathrm{Sb}$ \\
\hline \multirow{2}{*}{ Theodoxinae } & \multirow{2}{*}{4.05} & Theodoxus niloticus (Reeve 1856) & Dw, Pr or $\mathrm{Sb}$ \\
\hline & & Theodoxus sp. & Dw, Pr or $\mathrm{Sb}$ \\
\hline \multirow{3}{*}{ Thiaridae } & \multirow{3}{*}{2.79} & Melanoides pergracilis (Martens 1897) & $\mathrm{Sb}$ \\
\hline & & Melanoides tuberculata (Muller 1774) & $\mathrm{Sb}$ \\
\hline & & UD5 & Ps \\
\hline
\end{tabular}

Bivalve's class had four species belonging to three families (Crassostreidae, Cyrenoidae and Donacidae). Cyrenoididae and Crassostreidae were represented by one species each and Donacid (two genera) by two species. The relative density of these families was very low. This can be explained by the fact that Bivalves living in mangrove habitats are either attached to substrate or attached to the roots of mangrove plants. Most bivalves living on substrates are often buried in the substratum; this lifestyle makes them less visible than gastropods which are epibenthic. Another likely reason to explain less abundance of bivalves is that the mangrove wetland was temporally flooded with tidewater, and bivalves are obviously unable to tolerate long periods of exposure to air [32].

The previous works conducted by Plaziat [20], Bandel and Kowalke [21] and Ngo-Massou et al. [11] recorded respectively 24,18 and 12 species. These first results presume a decline in the species number of mollusc's community due to the damage experiences encountered in mangrove ecosystems in Cameroon [16, 18]. However, the present study with 34 species demonstrates easily that certain molluscs, especially some gastropods, are not greatly affected by the loss of vegetation cover; as they are able to quickly colonize disturbed areas [32].

Considering present observations, three species, Neritina adansoniana, $N$. lineolata (Neritinidae) and Pachymelania fusca var. mutans (Pachymelaniidae), found in this study, are reported for the first time. The species identified finally as Pachymelania sp.2 found here was suspected to be Terebralia palustris, a typical tropical species and the largest mangrove prosobranch gastropod [34] but its distribution extending across the mangrove habitats of the Indo-West-Pacific region, from eastern Africa to north-western Australia. The subtropical east coast of South Africa therefore represents its southernmost limit $[35,36]$. These species have enriched the inventory of mangrove molluscs in the country. The last data collection in the area brought up molluscs composition to 39 species including 26 genera and 19 families [11]. According to the nomenclators used in this survey [23, 24], the composition of mangrove molluscs in the Cameroon has been increased to 41 species, among 28 genera and 24 families.

Diversity is mainly influenced by changes in the environment that lead to less diversity. Several studies have shown a correlation between changes in the diversity and abundance of macrobenthos and the obvious variability of the environment such as the variability of habits (plants, sediment, ...) or sediment characteristics (mud, sand) [34, 37, 38]. Overall molluscan species recorded were mostly epifaunal, and were divided into four occupied habitats (deadwood, plant root, plant stem and substratum). Littorina spp. and an undetermined species belonging to Thiaridae were arboreal. Apart of substratum, roots and trunk of mangrove plants were good harvesting places for a variety of molluscan species. Thus Littorina spp., mostly Neritinidae species and Crassostrea gasar were densely found on stems, pneumatophores as well as on stilt roots of mangrove plants (Table 1). Similar observations were found in the West coast of India mangroves for Littorina spp. [39, 40], and for $C$. gasar in Nigeria [41]. The last species was the single Bivalve found on mangrove trees, yet, despite Gastropods living in sediment, most of them were attached on substrate. The habitats of Gastropods in mangrove forest are mangrove trees, above the mud surface and inside the sediment [42]. 
According to Plaziat [42], Isognomonidae and Ostreidae are abundant in mangrove areas because they have higher adaptation ability in changing environmental factors such as drought due to low tide and salinity. But the less abundance of Crassostrea gasar (Crassostreidae formely in Ostreidae family) in this work can be due to mangrove degradation, notably the abusive cut down of the wood especially Rizophora spp. used by the local population as firewood. The molluscs do not have thus any more support. Pachymelaniidae and Potamididae (especially Pachymelania and Tympanotonus genera) were dominated in terms of number of individual and relative abundance. Ngo-Massou et al. [11] found similar results in the Wouri river estuary. Prosobranch molluscs are the most abundant and most common in brackish waters in West Africa. Both types commonly known as periwinkles, live in calm waters where the substrate is muddy and rich in organic matter [43]. They are scavengers and are mostly found in mangroves and brackish marshes. Salinity, the nature of the substrate, the water depth and currents are the factors that affect their distribution in the coastal regions of West Africa [44].

The composition of molluscs in the study stations were significantly different. Upon the 34 species, the most species richness has been found in Yoyo (23 species; $\mathrm{MI}=2.8)$ while Londji has shown the lowest species richness ( 8 species; $\mathrm{MI}=1.1)$. Molluscs' abundance was very high in Douala $(166.7 \pm$ 74 ind. $\mathrm{m}^{-2}$ ), more than two and even four times in other stations (Table 2). This can be explained by the physical environmental stress and low nutritional quality of litter due to pollution of all kinds which may thus also contribute to the decrease of species proliferation in mangroves so that the fauna is dominated by a population of species that can adapt [43].The highest species diversity (ShannonWeaver index) was obtained in Douala $\left(\mathrm{H}^{\prime}=3.38\right)$ and the lowest in Limbe $\left(\mathrm{H}^{\prime}=2.36\right)$. The evenness index varied from 0.64 (Limbe) to 0.90 (Londji and Kribi). Common-species index has shown that molluscs' community was dominated by a few number of species in Limbe (0.85) while the distribution of species was closed to even in Londji (0.62). It indicates medium adverse impact of environmental stress or moderately polluted nature of water, in sampling stations, because of effluent discharge of domestic and industrial waste [46], on molluscan fauna. Also the lower diversity indices of molluscs is the outcome of uneven distribution of populations amongst the species, which is an indication of environmental stress in and around the selected sampling stations [47].

Table2. Mollusc's abundance and diversity in the different sampled stations. NP, Number of plots; NI, Number of individuals; NS, Number of species.

\begin{tabular}{|l|c|c|c|c|c|c|c|c|}
\hline Stations & NP & NI & NS & $\begin{array}{c}\text { Abundance } \\
\text { (ind.m-2) }\end{array}$ & $\begin{array}{c}\text { Margalef } \\
\text { index (MI) }\end{array}$ & $\begin{array}{c}\text { Shannon- } \\
\text { Weaver index } \\
\text { (H') }\end{array}$ & $\begin{array}{c}\text { Eveness } \\
\text { index (E') }\end{array}$ & $\begin{array}{c}\text { Common- } \\
\text { species index }\end{array}$ \\
\hline Limbe & 7 & 710 & 13 & $101.4 \pm 40$ & 1.8 & 2.36 & 0.64 & 0.85 \\
\hline Tiko & 12 & 499 & 10 & $41.6 \pm 28$ & 1.4 & 2.75 & 0.83 & 0.80 \\
\hline Douala & 56 & 9336 & 19 & $166.7 \pm 74$ & 2.0 & 3.38 & 0.80 & 0.84 \\
\hline Yoyo & 24 & 2894 & 23 & $120.6 \pm 56$ & 2.8 & 3.13 & 0.69 & 0.82 \\
\hline Londji & 6 & 445 & 8 & $74.2 \pm 33$ & 1.1 & 2.72 & 0.90 & 0.62 \\
\hline Kribi & 9 & 542 & 9 & $60.2 \pm 41$ & 1.3 & 2.86 & 0.90 & 0.67 \\
\hline
\end{tabular}

\subsection{Molluscs' Apportionment and Bioindication}

The presence of some species only at particular stations may be the fact that those species were tolerant or not of a variety of environmental stressors and individuals utilized behavioral and physiological mechanisms to survive adverse conditions $[36,48]$. But the level of vegetation degradation in mangrove areas exposed compromised individuals to potential predators for extended periods because they also have limited mobility [36]. Pachymelania fusca (28.6\%) followed by Tympanotonus radula (14.3\%) and Tympanotonus fuscatus $(9.12 \%)$ were the most abundant species. The three species represented more than the half of the total individuals (Table 3). The most frequent species observed in all stations from Limbe to Kribi were Pachymelania fusca $(95.21 \%)$, Tympanotonus radula (74.56\%) and T. fuscatus (68.42\%). Achatina achatina (2.63\%), Melanoides pergracilis (14.91\%), Potadoma liricincta (15.79\%), Pachymelania sp.2 (2.63\%) and the undetermined species that belongs to the Thiaridae (5.26\%) was found only in the Douala station. Littorina sp. (2.63\%) and Murex sp. (1.75\%) were observed only in Kribi station. Cyrenoida rosea $(4.38 \%)$, Neritina senegalensis $(0.88 \%)$ and the four undetermined species belonging to Neritinid were found in the Yoyo station (Table 3). Thais spp. and Littorina spp were only found at Londji, Kribi and Yoyo stations. These stations are much closed to the Atlantic Ocean and these species are known to be less tolerant to salinity variation [11]. The level of flooding in mangroves may cause changes in salinity which influences the distribution of some species. 
Ernest Flavien Kottè-Mapoko et al.

Table3. Quantitative parameters of molluscan species collected at the sampled stations (number of plots). RF, relative frequency; SRD, species relative density; NI, number of individuals; Oc, number of occurrences.

\begin{tabular}{|c|c|c|c|c|c|c|c|c|c|c|c|c|c|c|c|}
\hline \multirow[t]{2}{*}{ Species } & \multicolumn{2}{|c|}{$\begin{array}{c}\text { Limbe } \\
(7)\end{array}$} & \multicolumn{2}{|c|}{$\begin{array}{l}\text { Tiko } \\
(12)\end{array}$} & \multicolumn{2}{|c|}{$\begin{array}{c}\text { Douala } \\
(56)\end{array}$} & \multicolumn{2}{|c|}{$\begin{array}{l}\text { Yoyo } \\
\text { (24) }\end{array}$} & \multicolumn{2}{|c|}{$\begin{array}{c}\text { Londji } \\
(6)\end{array}$} & \multicolumn{2}{|c|}{$\begin{array}{c}\text { Kribi } \\
(9)\end{array}$} & \multirow{2}{*}{$\begin{array}{l}\text { Total } \\
\text { (114) }\end{array}$} & \multirow{2}{*}{$\begin{array}{l}\text { RF } \\
(\%)\end{array}$} & \multirow[t]{2}{*}{$\begin{array}{l}\text { SRD } \\
(\%)\end{array}$} \\
\hline & NI & Oc & NI & Oc & NI & Oc & NI & Oc & NI & Oc & NI & Oc & & & \\
\hline Achatina achatina & 0 & - & 0 & - & 8 & 3 & 0 & - & 0 & - & 0 & - & $8(3)$ & 2,63 & 0,05 \\
\hline Crassostrea gasar & 31 & 4 & 14 & 1 & 0 & - & 0 & - & 70 & 6 & 15 & 2 & $130(13)$ & 11,40 & 0,90 \\
\hline Cyrenoida rosea & 0 & - & 0 & - & 0 & - & 23 & 5 & 0 & - & 0 & - & $23(5)$ & 4,38 & 0,16 \\
\hline Egeria radiata & 0 & - & 50 & 5 & 0 & - & 140 & 12 & 0 & - & 0 & - & $190(17)$ & 14,91 & 1,32 \\
\hline Iphegenia rostrata & 19 & 3 & 0 & - & 180 & 14 & 28 & 4 & 0 & - & 0 & - & $227(21)$ & 18,42 & 1,57 \\
\hline Littorina angulifera & 33 & 3 & 48 & 4 & 0 & - & 12 & 6 & 15 & 2 & 0 & - & $108(15)$ & 13,15 & 0,75 \\
\hline Littorina sp. & 0 & - & 0 & - & 0 & & 0 & - & 0 & - & 17 & 3 & $17(3)$ & 2,63 & 0,12 \\
\hline Melanoides pergracilis & 0 & - & 0 & - & 134 & 17 & 0 & - & 0 & - & 0 & - & $134(17)$ & 14,91 & 0,93 \\
\hline Melanoides tuberculata & 0 & - & 0 & - & 219 & 26 & 23 & 9 & 0 & - & 0 & - & $242(35)$ & 30,70 & 1,68 \\
\hline Melanopsis sp. & 0 & - & 0 & - & 20 & 7 & 205 & 16 & 0 & - & 0 & - & $225(23)$ & 20,17 & 1,56 \\
\hline Murex sp. & 0 & - & 0 & - & 0 & - & 0 & - & 0 & - & 29 & 2 & $29(2)$ & 1,75 & 0,20 \\
\hline Neritilia rubida & 6 & 1 & 0 & - & 0 & - & 9 & 2 & 0 & - & 0 & - & $15(3)$ & 2,63 & 0,10 \\
\hline Neritina adansoniana & 0 & - & 0 & - & 89 & 4 & 5 & 1 & 0 & - & 0 & - & $94(5)$ & 4,38 & 0,65 \\
\hline Neritina glabrata & 13 & 2 & 42 & 9 & 223 & 31 & 0 & - & 0 & - & 0 & - & $278(42)$ & 36,84 & 1,93 \\
\hline Neritina lineolata & 11 & 1 & 0 & - & 0 & - & 26 & 2 & 0 & - & 0 & - & $37(3)$ & 2,63 & 0,26 \\
\hline Neritina senegalensis & 0 & - & 0 & - & 0 & - & 14 & 1 & 0 & - & 0 & - & $14(1)$ & 0,88 & 0,097 \\
\hline Pachymelania aurita & 0 & - & 0 & - & 272 & 22 & 170 & 13 & 0 & - & 0 & - & $442(35)$ & 30,70 & 3,06 \\
\hline Pachymelania Byronensis & 4 & 1 & 19 & 2 & 0 & - & 6 & 1 & 0 & - & 0 & - & $29(4)$ & 3,51 & 0,20 \\
\hline Pachymelania fusca & 348 & 5 & 175 & 10 & 2365 & 56 & 1035 & 24 & 71 & 6 & 137 & 8 & $4131(109)$ & 95,61 & 28,63 \\
\hline Pachymelania granifera & 5 & 2 & 0 & - & 820 & 14 & 0 & - & 35 & 8 & 59 & 3 & $919(27)$ & 23,68 & 6,37 \\
\hline Pachymelania mutans & 12 & 1 & 0 & - & 668 & 8 & 309 & 12 & 64 & 9 & 102 & 6 & $1155(36)$ & 31,57 & 8,00 \\
\hline Pachymelania sp.1. & 147 & 4 & 104 & 12 & 842 & 31 & 0 & - & 0 & - & 32 & 5 & $1125(52)$ & 45,61 & 7,80 \\
\hline Pachymelania sp. 2 & 0 & - & 0 & - & 69 & 3 & 0 & - & 0 & - & 0 & - & $69(3)$ & 2,63 & 0,48 \\
\hline Potadoma lirincta & 0 & - & 0 & - & 641 & 18 & 0 & - & 0 & - & 0 & - & $641(18)$ & 15,79 & 4,44 \\
\hline Thais callifera & 0 & - & 0 & - & 0 & - & 116 & 18 & 18 & 3 & 0 & - & $134(21)$ & 18,42 & 0,93 \\
\hline Theodoxus niloticus & 0 & - & 16 & 3 & 347 & 15 & 73 & 11 & 0 & - & 0 & - & $436(29)$ & 25,44 & 3,02 \\
\hline Theodoxus sp. & 0 & - & 0 & - & 111 & 3 & 37 & 4 & 0 & - & 0 & - & $148(7)$ & 6,14 & 1,02 \\
\hline Tympanotonus fuscatus & 76 & 7 & 21 & 2 & 595 & 40 & 410 & 20 & 132 & 4 & 83 & 5 & $1317(78)$ & 68,42 & 9,13 \\
\hline Tympanotonus radula & 5 & 1 & 10 & 3 & 1706 & 56 & 227 & 18 & 40 & 3 & 68 & 4 & $2056(85)$ & 74,56 & 14,25 \\
\hline UD1 & 0 & - & 0 & - & 0 & - & 2 & 1 & 0 & - & 0 & - & $2(1)$ & 0,88 & 0,01 \\
\hline UD2 & 0 & - & 0 & - & 0 & - & 12 & 1 & 0 & - & 0 & - & $12(1)$ & 0,88 & 0,08 \\
\hline UD3 & 0 & - & 0 & - & 0 & - & 7 & 2 & 0 & - & 0 & - & $7(2)$ & 1,75 & 0,05 \\
\hline$U D 4$ & 0 & - & 0 & - & 0 & - & 5 & 1 & 0 & - & 0 & - & $5(1)$ & 0,88 & 0,03 \\
\hline UD5 & 0 & - & 0 & - & 27 & 6 & 0 & - & 0 & - & 0 & - & $27(6)$ & 5,26 & 0,19 \\
\hline TOTAL & 710 & - & 499 & - & 9336 & - & 2894 & - & 445 & - & 542 & - & 14426 & - & 100 \\
\hline
\end{tabular}

The presence of three species (Pachymelania fusca, Tympanotonus fuscatus and T. radula) in all stations could suggest that those species were tolerant to anthropogenic disturbance. Indeed, Fusi et al. [49] assessed the presence of anthropogenic contaminants, such as sterols, PAHs, PCBs, DEHP, DDT and its metabolite p,p'-DDE and potentially toxic metals in sediment in some mangrove stands of Douala. Surveys in the neighboring country have shown the importance of Tympanotonus and Pachymelania communities in mangrove macrobenthos inventory in Nigeria [50, 51], where oil activities have changed environmental conditions of many lagoons. Likewise, petroleum products have been encountered in all mangrove areas of Cameroon, and serious oil spill from the Limbe refinery had damaged all mangrove stands along the Atlantic Ocean. The presence/absence of mollusc species could not alone determine the biological/ecological indicator species in mangrove forest because of the importance of environmental factors involved in this ecosystem functioning and the capacity of each species to adapt to immediate and deferred changes.

According to a dendrogram, two distinct zones could be distinguished at a similarity level of $24 \%$. The cluster indicates stations with similar community structure, revealing the similarity of stations based on their fauna abundance and composition. Douala forms a separate group than the other five stations, indicating a clear distinction between molluscs' communities that live in this zone and those in the others zones. In the second group, Limbe and Tiko were very closed (61\%), likewise Kribi and Londji were also very closed (63\%) and Yoyo form an isolated part of its own and is close with the other four stations at a similarity level of $28 \%$ (Figure 2). Cluster Analysis of species abundance permitted to distinguish two groups based on sampling stations. Most conspicuous is the Douala station standing differently from all the other stations. It seemed that the species from the Douala 
station could have significant behavior and adaptability capacities than in the other sampled stations. Some factors such as organic content, food availability and historical disturbances can also greatly influence the species richness and abundance of macrobenthos. This may also be explained by anthropogenic factors indirectly who may also influence molluscan communities, especially in areas with multiple sources of human stressors [52], where the dominance of few species may indicate systems subjected to organic enrichment and contaminated sediments [53].

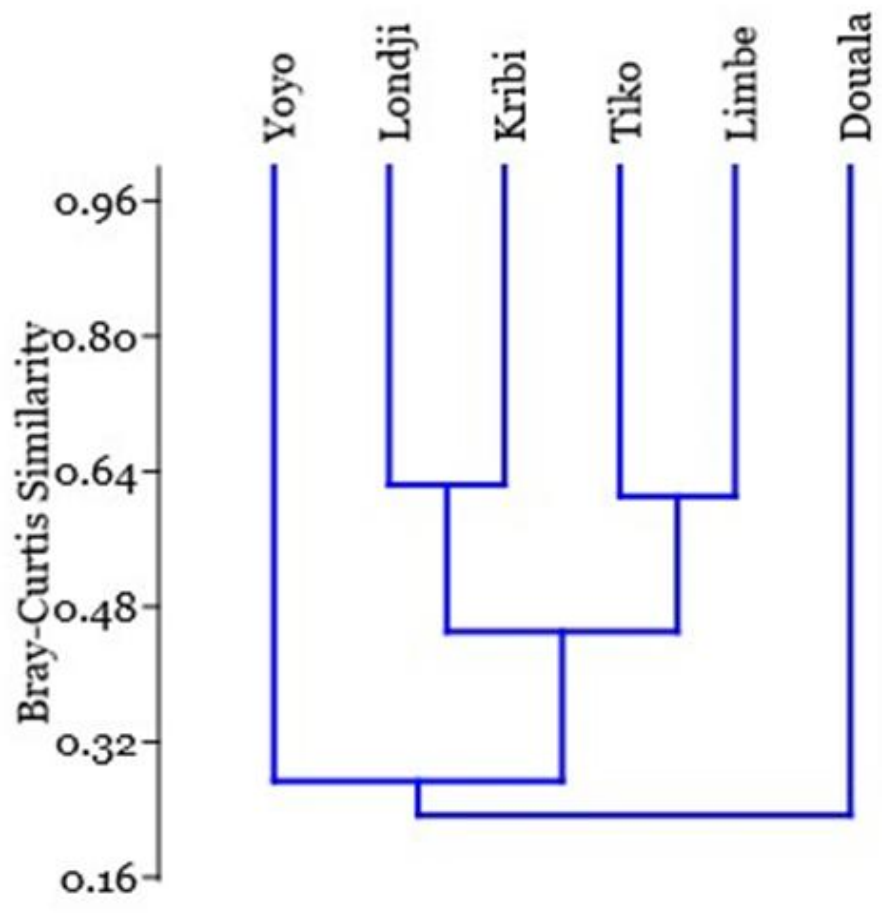

Figure2. Dendrogram showing similarity between study stations.

\section{CONCLUSION}

The present study has provided important baseline data on the diversity of mangrove molluscan in Cameroon. The census improved the composition up to 42 species, including 28 genera and 24 families. The enrichment has also concerned new data as the presence of Neritina adansoniana, $N$. lineolata and Pachymelania fusca var. mutans mentioned for the first time in this area. There was a significant difference in species assemblages among the six stations. Pachymelania fusca, Tympanotonus fuscatus and T. radula were found in all surveyed stations and these species appeared to be more tolerant to environmental and anthropogenic pressures. The determination of potential bioindicators in mangrove needed a complex mix of intra and extra factors due to the natural capacity of species to adapt to difficult environmental conditions represented by the mangrove ecosystem.

\section{REFERENCES}

[1] Dahdouh-Guebas F., Koedam N., Danielsen F., Sørensen M.K., Olwig M.F., Selvam V., Parish F., Burgess N.D., Topp-Jørgensen E., Hiraishi T., Karunagaran V.M., Rasmussen M.S., Hansen L.B., Quarto A. and Suryadiputra N. Coastal vegetation and the Asian tsunami. Science 311, 3738 (2006).

[2] Alongi D.M. Mangrove forests: resilience, protection from tsunamis, and responses to global climate change. Estuar. Coast. Shelf Sci. 76, 1-13 (2007).

[3] Schaffelke B., Mellors J. and Duke N.C. Water quality in the Great Barrier Reef region: responses of mangrove, seagrass and macroalgal communities. Mar. Pollut. Bull. 51, 279-296 (2005).

[4] Cannicci S., Bartolini F., Dahdouh-Guebas F., Fratini S., Litulo C., Macia A., Mrabu E.J., Penha-Lopes G. and Paula J. Effects of urban wastewater on crab and mollusc assemblages in equatorial and subtropical mangroves of East Africa. Estuar. Coast. Shelf Sci. 84 (3), 305-317 (2009). 
[5] Alongi D.M. Carbon payments for mangrove conservation: ecosystem constraints and uncertainties of sequestration potential. Environ. Sci. Policy 14: $462-470$ (2011).

[6] Din N. and Blasco F. Gestion des mangroves sous pression démographique et paupérisation. XIIème Congrès forestier Mondial, 21-28 septembre, Québec, Canada (2003).

[7] FAO (Food and Agriculture Organization). L'importance des forêts de mangrove pour la pêche, la faune sauvage et les ressources en eau en Afrique. Nat. Faune 24 (1), (2009).

[8] Kathiresan K. and Bingham B.L. Biology of Mangroves and Mangrove Ecosystems. Adv. Mar. Biol. 40, 81-251 (2001).

[9] Xuan Q.N., Vanreusel A., Thanh N.V. and Smol N. Biodiversity of Meiofauna in the intertidal Khe Nhan mudflat, Can Gio mangrove forest, Vietnam, with special emphasis of free living Nematodes. Ocean Sci. J. 42 (3), 135-152 (2007).

[10] Macintosh D.J., Ashton E.C. and Havanon S. Mangrove Rehabilitation and Intertidal Biodiversity: a Study in the Ranong Mangrove Ecosystem, Thailand. Estuar. Coast. Shelf Sci. 55, 331-345 (2002).

[11] Ngo-Massou V.M., Essomè-Koum G.L., Ngollo-Dina E. and Din N. Composition of macrobenthos in the Wouri River estuary mangrove, Douala, Cameroon. Afr. J. Mar. Sci. 34 (3), 349-360 (2012).

[12] Macintosh D.J. Ecology and productivity of Malaysian mangrove crab populations (Decapoda: Brachyura). Res. Manag. 354-377 (1984).

[13] Cannicci S., Burrows D., Fratini S., Lee S.Y., Smith III T.J., Offenberg J. and Dahdouh-Guebas F. Faunistic impact on vegetation structure and ecosystem function in mangrove forests. Aquat. Bot. 89 (2), 186-200 (2008).

[14] Nfotabong-Atheull A.A., Din N. and Dahdouh-Guebas F. Qualitative and quantitative characterization of mangrove vegetation structure and dynamics in peri-urban setting of Douala (Cameroon): an approach using air-borne imagery. Estuar. Coast. 36, 1181-1192 (2013).

[15] Din N., Saenger P., Priso R.J., Dibong D.S. and Blasco F. Logging activities in mangrove forests: A case study of Douala Cameroon. Afr. J. Environ. Sci. Technol. 2 (2), 22-30 (2008).

[16] Nfotabong-Atheull A.A., Din N., Longonje S.N., Koedam N. and Dahdouh-Guebas F. Commercial activities and subsistence utilization of mangrove forests around the Wouri estuary and the Douala-Edea reserve (Cameroon). J. Ethnobiol. Ethnomed. 5 (35), (2009).

[17] Din N. Mangrove du Cameroun: statut écologique et perspectives de gestion durable. Thèse d'état, Université de Yaoundé I, Cameroun (2001).

[18] Nfotabong-Atheull A.A., Din N., Essomè-Koum G.L., Satyanarayana B., Koedam N. and Dahdouh-Guebas F. Assessing forest products usage and local residents' perception of environmental changes in peri-urban and rural mangroves of Cameroon, Central Africa. J. Ethnobiol. Ethnomed. 7 (41), (2011).

[19] Essomè-Koum G.L., Ngo-Massou V.M., Kottè-Mapoko E.F., Bilong P., Din N. Diversity Shifts in the Mangrove Vegetation of the Rio del Rey Estuary (Cameroon). Inter. J. Res. Stud. Biosci. 5 (4): 6-14 (2017).

[20] Plaziat J.C. Repartition des mollusques amphibies de quelques littoraux et estuaires à mangroves (Nouvelle Calédonie et Cameroun). Haliotis 4, 17-167 (1974).

[21] Bandel K, Kowalke T. Gastropod fauna of the Cameroonian coasts. Helgol Mar. Res. 53, 129140 (1999).

[22] Ngo-Massou V.M., Essomè-Koum G.L., Kottè-Mapoko E. and Din N. Biology and Distribution of Mangrove Crabs in the Wouri River Estuary, Douala, Cameroon. J. W. Resour. Prot. 6, 236248 (2014).

[23] Bouchet P. and Rocroi J-P. Classification and Nomenclator of Gastropod Families. Malacology 47 (1-2), 1-397 (2005).

[24] Bouchet P. and Rocroi J-P. Nomenclator of Bivalve Families; with a classification of bivalve families by Bieler R., Carter J.G., Coan E.V. Malacology 52 (2), 1-184 (2010).

[25] Gerhardt A. Bioindicator species and their use in biomonitoring. In Environmental monitoring Inyang H.I. and Daniels J.L. Eds., EOLSS publisher/UNESCO Oxford volume 1, 77-123 (2009). 
[26] Gupta S.K. and Singh J. Evaluation of molluscs as sensitive indicator of heavy metal pollution in aquatic system: a review. IIOAB J. 2 (1), 49-57 (2011).

[27] Gupta k., Nandy A., Banerjee K. and Talapatra S.N. Biomonitoring of river Ganga bank by identifying mollusc species as an indicator. Inter. Lett. nat. Sci. 37, 71-77 (2015).

[28] Ludwig J.A. and Reynolds J.F. Statistical ecology: a primer on methods and computing, John Willey \& Sons, Inc.: New York, USA (1988).

[29] Emberton K.C., Pearce T.A., Kasigwa P.F., Tattersfield P. and Habibu Z. High diversity and regional endemism in land-snails of eastern Tanzania. Biodivers. Conserv. 6, 1123-1136 (1997).

[30] Hammer Ø., Harper D.A.T. and Ryan P.D. PAST: Paleontological Statistics software package for education and data analysis. Palaeontol. Electron. 4 (1), 1-9 (2001).

[31] Budiarsa A.A. and Rizal S. Community structure of macrozoobenthos in mangrove ecosystem, Kutai National Park, East Kalimantan. Inter. J. Sci. Eng. 7 (1), 91-94 (2014).

[32] Li Y.F., Xu R.L. and Wang C.F. The community structure of molluscs in three different wetland types in the Qi'ao-Dan'gan Island Mangrove Nature Reserve at Qi'ao Island, Pearl River estuary, China. Zool. Stud. 51 (6), 745-754 (2012).

[33] Bosire J.O., Dahdouh-Guebas F., Walton M., Crona B.I., Lewis III R.R., Field C., Kairo J.G. and Koedam N. Functionality of restored mangroves: a review. Aquat. Bot. 89, 251-259 (2008).

[34] Pape E., Muthumbi A., Kamanu C.P. and Vanreusel A. Size-dependent distribution and feeding habits of Terebralia palustris in mangrove habitats of Gazi Bay, Kenya. Estuar. Coast. Shelf Sci. 76, 797-808 (2008).

[35] Wells F.E. and Lalli C.M. Aspects of the ecology of the mudwhelks Terebralia palustris and T. semistriata in northwestern Australia. In The marine flora and fauna of Dampier, Western Australia, Wells F.E., Walker D.I., Jones D.S., Eds., Western Australian Museum, Perth, Australia, 193-208 (2003).

[36] Raw J.L., Perissinotto R., Taylor R.H., Miranda N.A.F. and Peer N. Decline of Terebralia palustris in South African mangroves. Afr. J. Mar. Sci. 36 (4), 517-522 (2014).

[37] Lindegarth M. and Hoskin M.G. Patterns of distribution of macrofauna in different types of estuarine, soft-sediment habitats adjacent to urban and non-urban areas. Estuar. Coast. Shelf Sci. 52, 237-247 (2001).

[38] Ashton E.C., Macintosh D.J. and Hogarth P.J. A baseline study of the diversity and community ecology of crab and molluscan macrofauna in the Sematan mangrove forest, Sarawak, Malaysia. J. Trop. Ecol. 19 (2), 127-14 (2003).

[39] Kurhe A.R., Mane U.H. and Pawar B.A. Studies on the ecology of gastropod molluscs of mangrove swamps of Bhatye Estuary. J. Exp. Zool. India 12 (1), $23-28$ (2009).

[40] Khade S.N. and Mane U.H. Diversity of Bivalve and Gastropod Molluscs in Mangrove ecosystem from selected sites of Raigad district, Maharashtra, West coast of India. Recent Res. Sci. Technol. 4 (10), 16-20 (2012).

[41] Ansa E.J. and Bashir R.M. Fishery and culture potentials of the mangrove oyster (Crassostrea gasar) in Nigeria. Res. J. Biol. Sci. 2 (4), 392-394 (2007).

[42] Plaziat J.C. Mollusk distribution in the mangal. In Por F. \& Dor I. (eds), Hydrobiology of the mangal. Dev. Hydrobiol. 20, 111-143 (1984).

[43] Jamabo N. and Chinda A. Aspects of the Ecology of Tympanotonus fuscatus var fuscatus (Linnaeus, 1758) in the Mangrove Swamps of the Upper Bonny River, Niger Delta, Nigeria. Curr. Res. J. Biol. Sci. 2 (1): $42-47$ (2010).

[44] Deekae S.N. The ecological distribution of mangrove mollusks in the Bonny-New calabar Rivers System of Niger Delta. M.Sc. Thesis, University of Port Harcourt, Choba, Nigeria (1987).

[45] Lee S.Y. 2008. Mangrove macrobenthos: Assemblages, services and Linkages. J. Sea Res. 59, 16-29 (2008).

[46] Kankal N.C., Lokhande K.S., Indurkar M.M. and Wate S.R. Biodiversity of zooplankton and zoobenthos at Thane Creek, Mumbai in west coast of India. Asian J. Exp. Sci. 25 (2), 63-71 (2011). 
[47] Banerjee K., Chakraborty S., Paul R., Bal G., Zaman S., Pramanick P., Amin G., Fazli P. and Mitra A. Macrobenthic molluscan diversity in the major intertidal zones of the maritime states of India. J. Environ. Sci. Pollut. Res. 1 (1), 8-11 (2015).

[48] Penha-Lopes G., Bartolini F., Limbu S., Cannicci S., Mgaya Y., Kristensen E. and Paula J. Ecosystem engineering potential of the gastropod Terebralia palustris (Linnaeus, 1767) in mangrove wastewater wetlands - a controlled mesocosm experiment. Environ. Pollut. 158, 258266 (2010).

[49] Fusi M., Beone G.M., Suciu N.A., Sacchi A., Trevisan M., Capri E., Daffonchio D., Din N., Dahdouh-Guebas F. and Cannicci S. Ecological status and source of anthropogenic contaminants in mangrove of Wouri river estuary (Cameroon). Mar. Pollut. Bull. 109 (2), 723-733 (2016).

[50] Esenowo I.K. and Ugwumba A.A.A. Composition and abundance of macrobenthos in Majidun river Ikorordu Lagos State, Nigeria. Res. J. Biol. Sci. 5 (8), 556-560 (2010).

[51] Uwadiae R.E. Spartial patterns in diversity and distribution of benthic molluscs in a weak tidal tropical lagoon. Inter. J. Mar. Sci. 3 (14), 11-120 (2013).

[52] Hewitt J.E., Anderson M.J. and Thrush S.F. Assessing and monitoring ecological community health in marine systems. Ecol. Appl. 15, 942-953 (2005).

[53] Azrina M.Z., Yap C.K., Rahim I.A., Ismail A. and Tan S.G. Anthropogenic impacts on the distribution and biodiversity of benthic macroinvertebrates and water quality of the Langat River, Peninsular Malaysia. Ecotoxicol. Environ. Saf. 64, 337-347 (2006). 